\title{
An Archaeological Assessment of 47 Acres at Friedrich Park in San Antonio, Texas
}

Jeffrey J. Durst

Center for Archaeological Research

Follow this and additional works at: https://scholarworks.sfasu.edu/ita

Part of the American Material Culture Commons, Archaeological Anthropology Commons, Environmental Studies Commons, Other American Studies Commons, Other Arts and Humanities Commons, Other History of Art, Architecture, and Archaeology Commons, and the United States History Commons

Tell us how this article helped you.

This Article is brought to you for free and open access by the Center for Regional Heritage Research at SFA ScholarWorks. It has been accepted for inclusion in Index of Texas Archaeology: Open Access Gray Literature from the Lone Star State by an authorized editor of SFA ScholarWorks. For more information, please contact cdsscholarworks@sfasu.edu. 


\section{An Archaeological Assessment of 47 Acres at Friedrich Park in San Antonio, Texas}

\section{Creative Commons License}

\section{(c) (1) \&}

This work is licensed under a Creative Commons Attribution-NonCommercial 4.0 International License 


\section{AN ARCHAEOLOGICAL ASSESSMENT OF 47 ACRES AT FRIEDRICH PARK IN SAN ANTONIO, TEXAS}

Jeffrey J. Durst

Center for Archaeological Research

The University of Texas at San Antonio

Archaeological Survey Report, No. 235

1995 



\title{
AN ARCHAEOLOGICAL ASSESSMENT OF 47 ACRES AT FRIEDRICH PARK IN SAN ANTONIO, TEXAS
}

\author{
Jeffrey J. Durst \\ Robert J. Hard and C. Britt Bousman \\ Principal Investigators
}

Texas Antiquities Comımitee Permit No. 1562

C) Copyright

Center for Archaeological Research The University of Texas at San Antonio

Archaeological Survey Report, No. 235 

The following information is provided in accordance with the General Rules of Practice and Procedure, Chapter 41.11 (Investigative Reports), Texas Antiquities Committee:

1. Type of Investigation: Survey

2. Project Name: Friedrich Park

3. County: Bexar

4. Principal investigators: Robert J. Hard and C. Britt Bousman

5. Name and location of sponsoring agency: San Antonio Department of Parks and Recreation; P. O. Box 839966, San Antonio, Texas, 78283-3966

6. Texas Antiquities Committee Permit No.: 1562

7. Published by the Center for Archaeological Research, The University of Texas at San Antonio, San Antonio, Texas 78249-0658, 1995.

A list of publications offered by the Center for Archaeological Research can be obtained by sending $\$ 1.00$ to the Center for Archaeological Research, The University of Texas at San Antonio, 6900 N. Loop 1604 West, San Antonio, Texas 78249-0658. 



\begin{abstract}
From May 24, 1995 to June 20, 1995, the Center for Archaeological Research conducted a cultural resources survey of 47 acres owned by the San Antonio Parks and Recreation Department. The survey covered three parcels of property adjoining the existing Friedrich Wilderness Park located on Milsa Road in northern Bexar County, Texas.
\end{abstract}

ABSTRACT

As a result of surface examination and subsurface testing, CAR has determined that no further investigations are recommended for Areas $\mathrm{A}$ and $\mathrm{B}$. In Area $\mathrm{C}$, where a historic house site is located, three alternative recommendations are offered, depending on future plans of the Parks and Recreation Department. 



\section{CONTENTS}

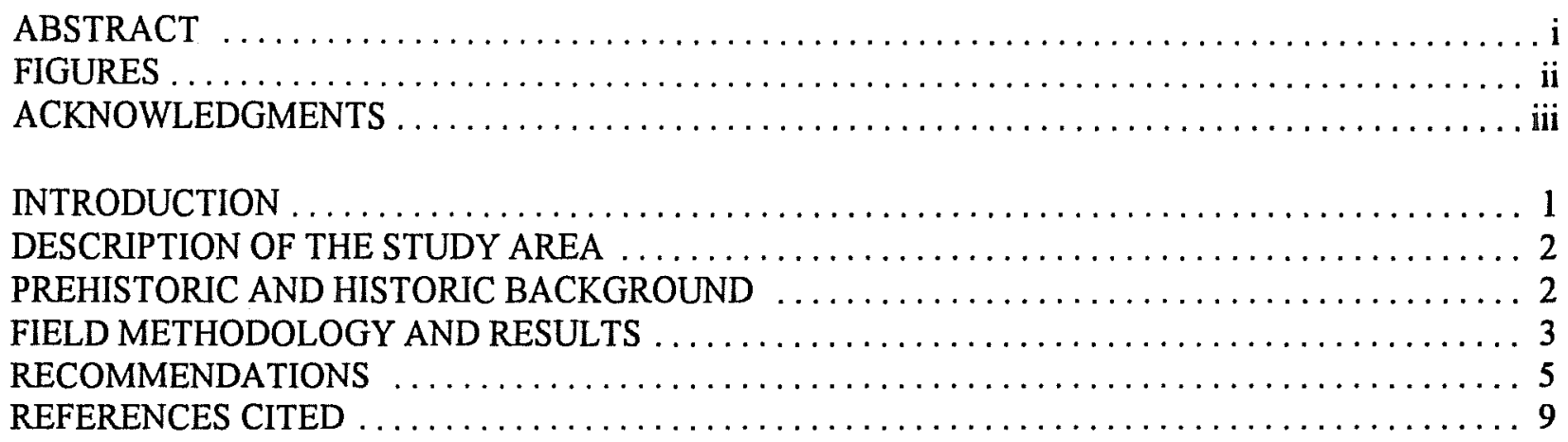

\section{FIGURES}

1. Project area and location of survey areas and historic site $\ldots \ldots \ldots \ldots \ldots \ldots \ldots \ldots \ldots \ldots \ldots \ldots$

2. Park map with locations of previously recorded archaeological sites. $\ldots \ldots \ldots \ldots \ldots \ldots \ldots \ldots, 4$

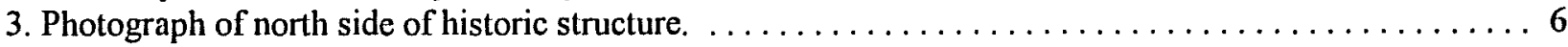

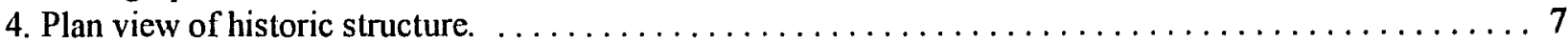

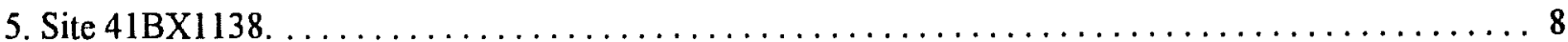





\section{ACKNOWLEDGMENTS}

I wish to acknowledge the San Antonio Parks and Recreation Department for affording the Center for Archaeological Research the opportunity to participate in this project. I would especially like to thank Dale Bransford for his help and cooperation throughout the project.
During the project the co-principal investigators were Robert J. Hard, director of CAR, and C.Britt Bousman, associate director of CAR. I would like to thank them both for their help and guidance during the fieldwork and write-up of the project. I would also like to thank Marcie Renner, CAR editor, for preparing the report for final publication. 

This page has been

redacted because it

contains restricted

information. 



\section{DESCRIPTION OF THE STUDY AREA}

The project area is in a steep rocky range approximately six kilometers north of Loop 1604 in northern Bexar County, Texas. The soil associations are the Brackett-Tarrant association on the 29-acre parcel; Tarrant association, gently undulating, on the 7.2-acre parcel; and Tarrant association, hilly, on the 10.8-acre parcel. These three soil associations are made up of shallow, calcareous clay loams and clays that consist of stones, cobblestones, flagstones, and gravel scattered on the surface and distributed through the profile (Taylor et al. 1991). Stones, limestone fragments, and exposed bedrock cover from $\mathbf{4 0}$ to 70 percent of the surface on the 29- and 10.8-acre parcels. These parcels also display, in some areas, outcrops of hard limestone which form steep escarpments and deep canyons. Tarrant soils 20 to $50 \mathrm{~cm}$ in depth are found on the nearly level 7.2-acre parcel. Vegetation in the hilly areas consists primarily of cedar-juniper-scrub forest with moderate to heavy undergrowth. In the more level areas, live oak trees create a dense canopy reducing the density of the understory.

\section{PREHISTORIC AND HISTORIC BACKGROUND}

As of June 1995, 1,135 archaeological sites had been documented in Bexar County. In close proximity to the project area, a full archaeological and historical assessment of Camp Bullis was completed by CAR in 1978. The study documented 42 previously unrecorded sites, adding to the previously recorded 30 sites (Gerstle et. al. 1978). A 1988 reconnaissance survey conducted by Prewitt and Associates recorded an additional eight sites at Camp Bullis (Quigg 1988). The following year a 100 percent pedestrian survey of 1,833 acres on Camp Bullis produced another 24 previously unrecorded sites, both prehistoric and historic (Boyd et al. 1990). In addition to fieldwork completed, a comprehensive research context for Camp Bullis was also compiled in 1993 (Hines 1993).

A survey conducted in 1977 by CAR recorded 29 sites in the nearby Salado Creek watershed area
(Brown et al. 1977). Sites recorded as a result of these survey projects cover a time span from Paleoindian (8000-9000 B.C.) to the Historic period (Hester 1976, 1978; Quigg 1988). Other projects have recorded numerous small sites within a 10 -mile radius of the project area.

The project area falls within the archaeologically defined Central Texas zone, bordering along the southern edge of the Balcones Escarpment. The project area, and Bexar County in general, are characterized by the presence of a sparse sample of cultural materials from the earliest Paleoindian period (9000-6500 B.C.). The following Archaic period (ca. 6500 B.C.-A.D. 700) dominates the prehistoric cultural record in Bexar County and prehistoric cultural materials recovered from Friedrich Park during a 1975 CAR survey adhere to this pattern.

Archaic sites generally found in the northern Bexar County area include: burned rock middens, rockshelters, quarry workshops, temporary open campsites, permanent (base) open campsites and lithic scatters. Technological changes between the Paleoindian period and the Archaic period are evident in the tool assemblage, reflecting shifts in settlement and subsistence patterns (Hester 1976).

The Late Prehistoric period (A.D. 900-1700) is characterized by two new technological additions, the bow and arrow and ceramics. Sites relating to this period, which is terminated by Spanish colonial occupation in the region, are not as common as Archaic sites in Bexar County.

The Historic period in Bexar County begins with the construction of the Spanish Villa San Fernando de Bexar, the first civil settlement in Texas (Fox 1978). In the early nineteenth century Mexico gained independence from Spain, and Texas was opened to colonization from the United States and Europe through empresario contracts. At this time Anglo-Americans gradually began to settle in the area. Early settlers documented the presence of at least three Indian groups, Lipan Apache, Comanche, and Tonkawa. 

During the early statehood period in Texas, land grants of various size were awarded to individuals living in the state. The property on which Friedrich Park now sits is a portion of an original "head right," granted to the head of a family residing in the state before 1837. This type of grant entitled the head of a family to 640 acres within the borders of the state. Often these land grants were purchased by land speculators who would buy the original grantee's rights to the property. Ludovic Colqhoun was a speculator in the Bexar County area and is shown to be the land owner of this 640-acre parcel of land as early as the 1840s (Ownership Map, 1836, Bexar County. General Land Office, Austin, Texas). In the early 1900 s a portion of this 640 -acre parcel was purchased by Winn Traylor and subdivided into smaller plots (Plat book 980:19. Office of Bexar County Clerk, Bexar County Courthouse, San Antonio, Texas). The 7.2 acres recently annexed by Friedrich Park was a plot in the Traylor Subdivision. During the late 1920s or early 1930 s a stone house was constructed on this 7.2acre plot which now fronts on Milsa Road.

Within the park itself a full archaeological assessment was completed by CAR in 1975 . Four sites were recorded during this survey. These sites are small, temporarily utilized areas, none of which had access to permanent surface water.

Site 1 (41BX295) (Figure 2) was recorded as consisting of a very light scatter of chert debitage, miscellaneous artifacts and a few projectile points (Smith and McDonald 1975). It is defined as being a temporary campsite used for sporadic hunting and gathering activities, utilized from the Late Archaic to the Late Prehistoric (Smith and McDonald 1975).

Site 2 (41BX296) (Figure 2) was recorded as another area of short term use, utilized primarily as a lithic procurement area for chert extraction, core preparation and core reduction. Site 3 (41BX297) (Figure 2) was described as a more extensive lithic procurement site with numerous cores and quarry blank fragments being noted and left in place (Smith and McDonald 1975). All indications are that this site, too, was utilized only on a temporary basis.
Site 4 (41BX298) was found at the same elevation as Site 2 , and is also a lithic procurement site, very small in size, with the lithic debris being very sparse and scattered. This site was also utilized only on a temporary basis.

\section{FIELD METHODOLOGY AND RESULTS}

Investigation of the project area included pedestrian survey and shovel tests in areas with potential for buried deposits. The survey was divided into three separate land parcels (Figure 1). Area A covered the 29-acre parcel at the south-west corner of the park; Area $B$ covered the 10.8-acre parcel on the northern most edge of the park; and area $C$ covered the 7.2acre parcel on the eastern side of the park.

The survey was conducted by two- and three-person teams traversing the property at $30-\mathrm{m}$ intervals. The terrain in Areas A and B is extremely steep and rugged. Top soil is slight to none in these areas and subsequently no shovel tests were carried out in these areas. No occupation or activity sites were found in either of these two areas.

The terrain in Area $\mathrm{C}$ is flat to slightly undulating. This area was also surveyed using transects at $30-\mathrm{m}$ intervals. Soil deposition varies from $0-50 \mathrm{~cm}$ in depth and a systematic shovel testing of this area was conducted at $30-\mathrm{m}$ intervals. Thirty-two shovel tests were completed in this area, none of which produced cultural material.

The remains of a historic house are located in Area $\mathrm{C}$ (Figure 1). The building was constructed of stone and mortar. The remains consists of four walls, still partially standing, and a chimney. Construction method and surrounding surface artifact scatters, including glass fragments and ceramic sherds, indicate that the house was probably built in the late 1920 s or early 1930 s.

Trees growing inside and next to the structure have caused damage by pushing in portions of the stone walls. None of the wooden infrastructure of the 

This page has been

redacted because it

contains restricted

information. 

house is remaining, only the four partial outer stone walls and the stone fireplace lined with glazed fire bricks remain. The bricks used in the construction of the fireplace are imprinted with a "STANDARD" brand and are dated to between 1919 and 1931 (Gurcke 1987). The structure was photographed (Figure 3) and a plan view of the four walls was drawn (Figure 4).

A possible unlined privy was located approximately $30 \mathrm{~m}$ north of the house. It consists of a slight depression approximately $1-x-1-m$ surrounded by several pieces of decaying lumber. No evidence, however, of outbuildings (barns, sheds, etc.) was uncovered during the examination of the area surrounding the house. No well or evidence of a possible location of a well was encountered, but no permanent water source is located near the house.

Because of the locations of already established features and the probability of additional features, a 30-m radius has been delineated as the site impact boundary (Figure 5). The site has been assigned the archaeological site trinomial 41BX1138.

In addition to the survey conducted on the newly acquired properties, a reexamination and assessment of the four previously recorded sites in the park was conducted. Site 1 (41BX295) was relocated and has apparently been scoured heavily by artifact hunters as there is very little remaining evidence of this site. Site 2 (41BX296) was relocated and appears to be in stable condition with a close resemblance to the description given in the 1975 survey report (Smith and McDonald 1975). Site 3 (41BX297) and site 4 (4IBX298) were also relocated and appear to have received little, if any, damage.

\section{SUMMARY AND RECOMMENDATIONS}

Areas A and B are located in steep, rugged terrain with only slight soil deposition. Survey of these two areas produced no cultural material and no further work is recommended for these two areas. Area $\mathrm{C}$ is in a much flatter area with deeper soil deposits, however, shovel testing in this area produced no buried cultural material.

Area $\mathrm{C}$ does contain a historic site with the remains of a standing house dating to the late 1920 s or early $1930 \mathrm{~s}$. The building no longer retains structural integrity so as an architectural feature is not eligible for nomination to the National Register of Historic Places. However, further testing and archival research would be required to determine if, as a historic archaeological site, it is eligible for nomination to the National Register. Should the Parks and Recreation Department want to learn the history of the location for interpretive purposes, an archival project could be done.

\section{RECOMMENDATIONS}

No further work is recommended for Areas A and B. The following recommendations are made for site 41BX1138.

1) If the site is not to be impacted by future park development, it is recommended that the site be fenced off to protect it from vandalism by park visitors.

2) If there is going to be nearby construction taking place in the park, then the site should be protected by a fence and/or by having an archaeologist monitor the critical phases of construction.

3) Should the site be impacted by park development, then a program of archival research and archaeological testing should be conducted. 



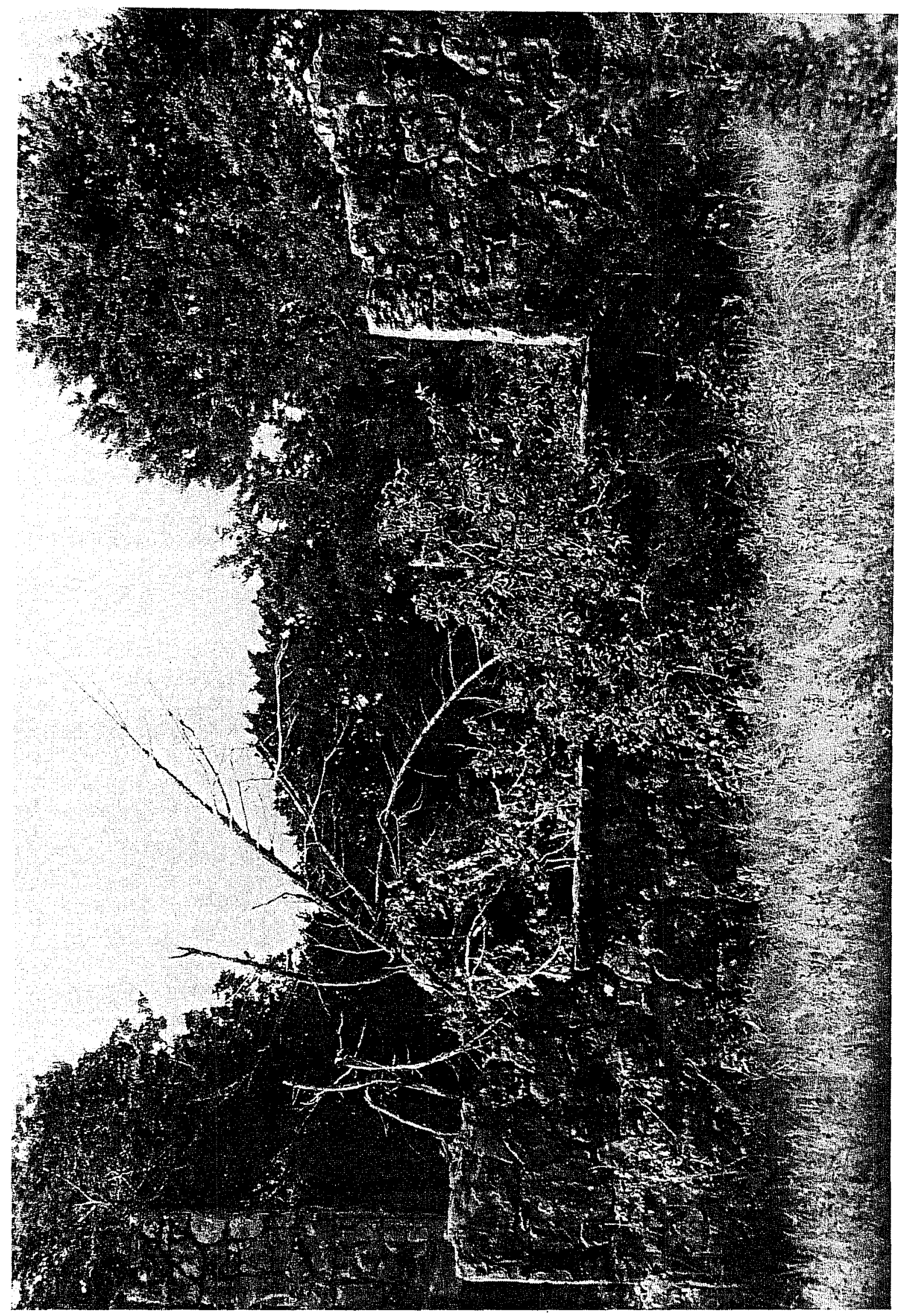

ปั. 



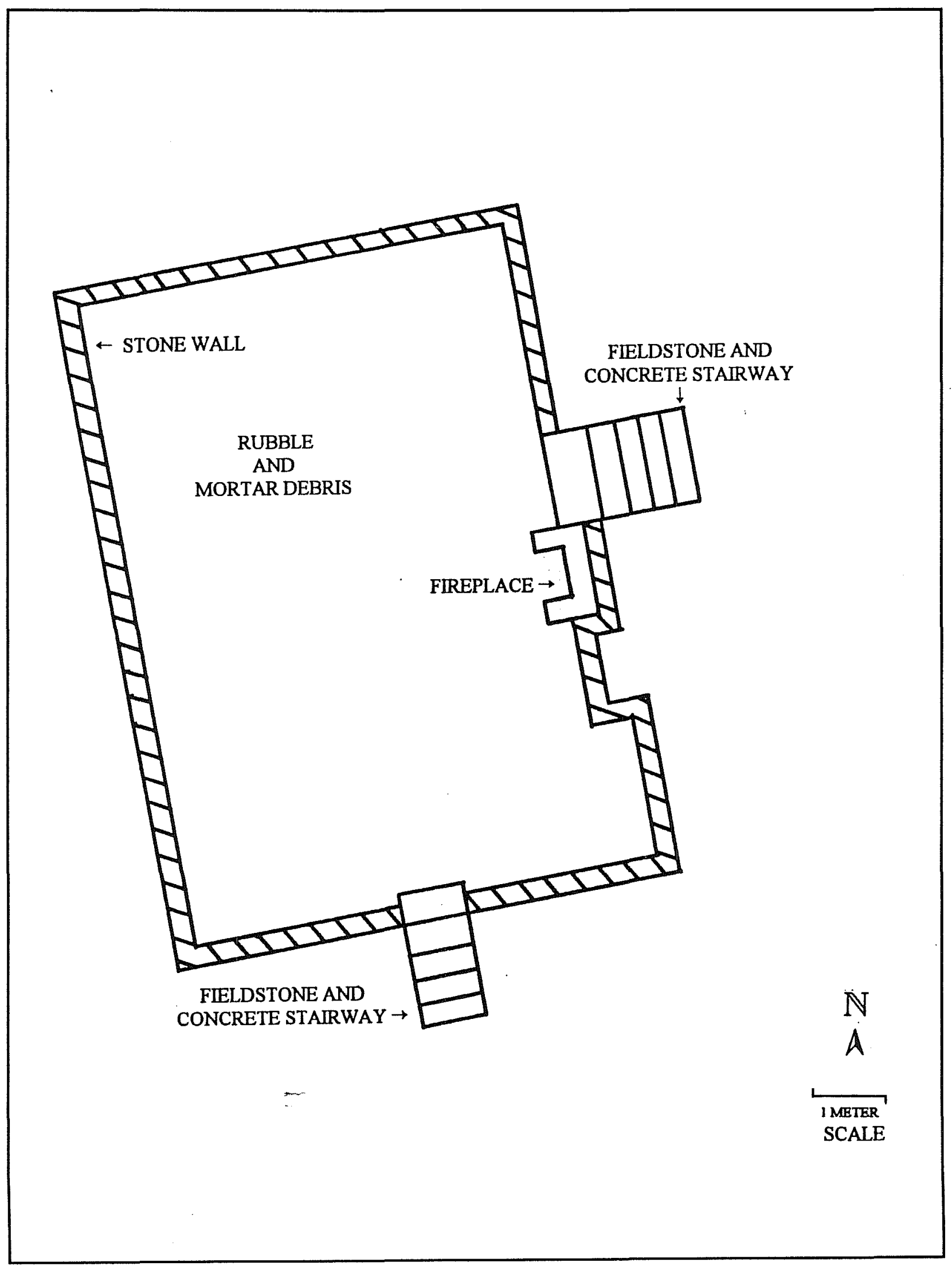

Figure 4. Plan view of historic structure. 



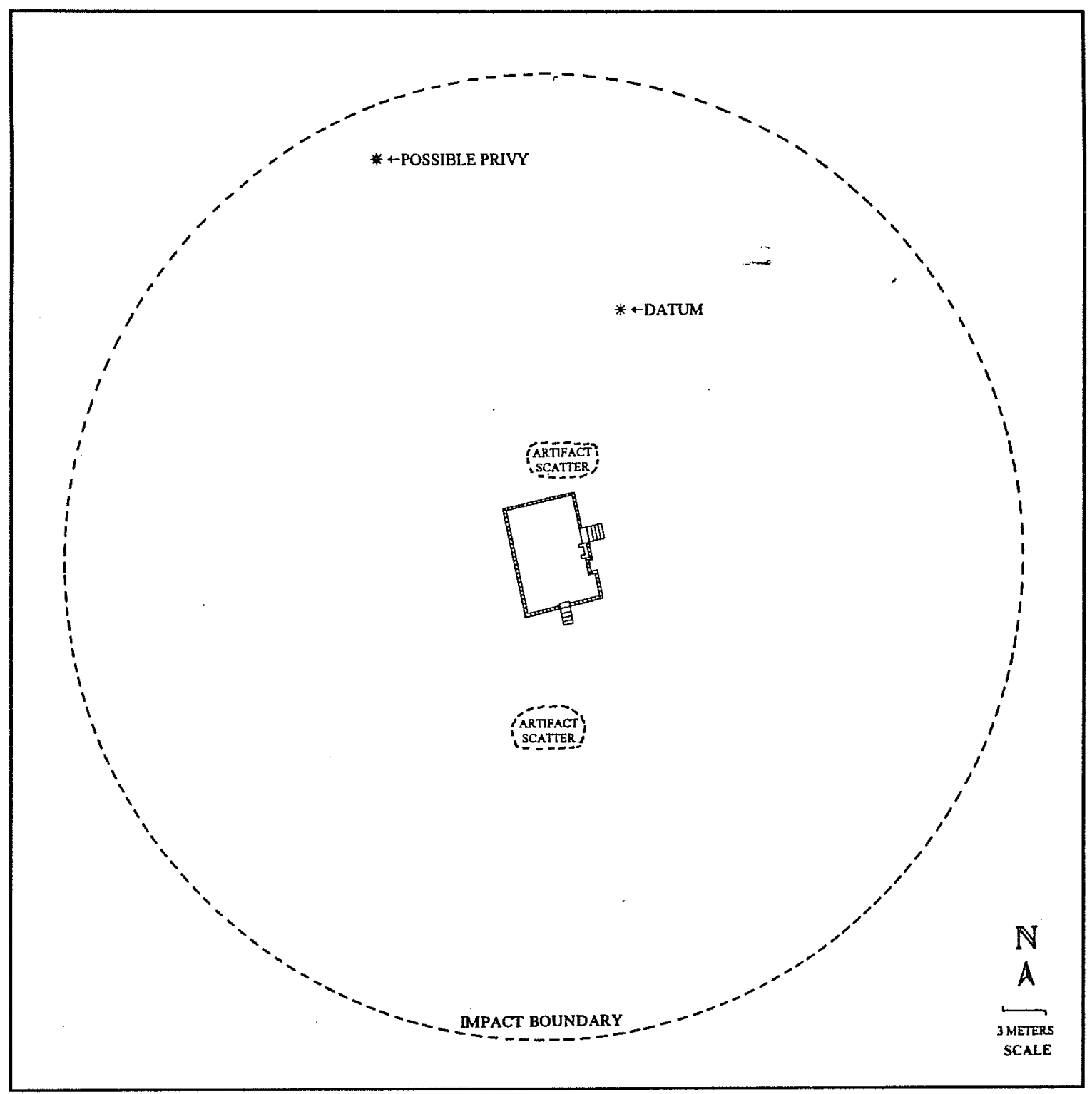

Figure 5. Site 4lBXI138. 



\section{REFERENCES CITED}

Boyd, D. K., I. W. Cox, and H. G. Uecker

1990 Archeological and Historical Investigations at Camp Bullis, Bexar and Comal Counties, Texas: The 1989 Season. Reports of Investigations, No. 75. Prewitt and Associates, Inc., Austin.

Brown, D., P. Lukowski, T. R. Hester, and J. D. Eaton

1977 Archaeological Assessment of Two Sites in the Vicinity of Floodwater Retarding Structure No. 11, Salado Creek Watershed, Bexar County, Texas. Archaeological Survey Report, No. 35, Center for Archaeological Research, The University of Texas at San Antonio.

Fox, A.

1978 Historical Background. In The Fort Sam Houston Project: An Archaeological and Historical Assessment, A Gerstle, T. C. Kelly, and C. Assad. Archacological Survey Report, No. 40, Center for Archaeological Research, The University of Texas at San Antonio.

Gerstle, A., T. C. Kelly, and C. Assad

1978 The Fort Sam Houston Project: An Archaeological and Historical Assessment. Archaeological Survey Report, No. 40, Center for Archaeological Research, The University of Texas at San Antonio.

Gurcke, K.

1987 Bricks and Brickmaking: A Handbook for Historical Archaeology. University of Idaho Press, Moscow.
Hester, T. R.

1976 The Texas Archaic: A Symposium. Special Report, No. 2, Center for Archaeological Research, The University of Texas at San Antonio.

1978 Background to the Archaeology of Chaparrosa Ranch, Southern Texas. Special Report, No. 6, Center for Archaeological Research, The University of Texas at San Antonio.

Hines, M. H.

1993 Prehistoric Research Context for Camp Bullis and Fort Sam Houston, Bexar and Comal Counties, Texas. Technical Reports, No. 16, Prewitt and Associates, Austin.

Quigg, J. M.

1988 Cultural Resources Reconnaissance in Secondary Impact Areas Along Salado Creek at Brooke Army Medical Center, Fort Sam Houston and Camp Bullis, Bexar County, Texas. Technical Reports, No. 5, Prewitt and Associates, Austin.

Smith, H. P., and K. McDonald,

1975 An Archaeological Survey of Friedrich Park, Bexar County, Texas. Archaeological Survey Report, No. 12, Center for Archaeological Research, The University of Texas at San Antonio.

Taylor, F. B., R. B. Hailey, and L. Richmond 1991 Soil Survey of Bexar County, Texas. United States Department of Agriculture, Soil Conservation Service. 
